Proc. Estonian Acad. Sci. Phys. Math., 2007, 56, 2, 162-169

\title{
Load transfer from the growing fibre into the growing medium: application to plant leaf growth
}

\author{
Natalya Kizilova \\ Department of Theoretical Mechanics, Kharkov National University, Svobody Sq. 4, 61077 \\ Kharkov, Ukraine; nnk_@bk.ru \\ Received 15 January 2007

\begin{abstract}
Biological materials change their mass, shape, and porosity during the growth and possess high strength and durability at general lightweight design. Biological tissues are considered to be inhomogeneous anisotropic multiphase composites reinforced by fibres. A $2 \mathrm{D}$ problem of the load transfer from the growing fibre into the growing plate with different own growth rates and viscosity is considered in this paper. Rheology of the growing biological tissue is described by a modified Maxwell model of viscoelastic media. Numerical calculations of the growth velocity and stress fields are carried out. The influence of rheological parameters of two media on the stress-strain state is investigated. It is shown that the stress field may provide local coordinated growth of the fibres and the plate when the rheological parameters of two materials are different and anisotropic growth is observed.
\end{abstract}

Key words: growing continuous media, stress-strain state, Maxwell body, load transfer.

\section{INTRODUCTION}

The modelling of the biological growth is a promising bias of the contemporary mechanics of continuous media, which is connected with tissue engineering and manufacturing the novel types of composites for biomedical and technical applications. Biological tissues can be considered as multiphase continuous media composed of a solid porous skeleton (cellular walls, membranes, extracellular substances, conducting vessels) filled with liquids (intracellular, interstitial and delivering fluids). The delivering fluids contain dissolved substances that can be absorbed by a solid phase providing the mass increase of a growing body due to increase in the volume (surface or volumetric growth) and decrease in porosity 
(inner growth or remodelling) $\left.{ }^{1,2}\right]$. In growing plants cell expansion is produced by creating a driving force for water uptake by decreasing hydrostatic pressure (turgor) through stress relaxation in the cell wall $\left[^{3}\right]$. Orientation of the newformed cell walls, conducting elements, and extracellular fibres is determined by the principals of the stress tensor. Cells are sensitive to the stress, and the threshold is $\sigma^{*}=0.03-0.05 \mathrm{MPa}\left[{ }^{4}\right]$. In that way the biomaterials with optimal mechanical properties (maximal strength for the given external load at minimal total weight) may be produced by the growth at certain conditions.

Numerous experimental observations and measurements of animal and plant tissues have revealed that tension stimulates growth in the corresponding direction while compression depresses it, and there is a linear dependence between the growth rate and the stress tensors. The Maxwell model of the viscoelastic fluid has been used for modelling the growth of the spine $\left[{ }^{5}\right]$, plant roots $\left[{ }^{6}\right]$ and leaves $\left[{ }^{7,8}\right]$, cellular monolayers $\left[{ }^{9}\right]$, and laminated tissues $\left[{ }^{10}\right]$ at different loads. Comparison of the numerical calculations and experimental measurements of the growth kinematics at different conditions poses an inverse problem for determination of the rheological parameters of the Maxwell model. Many measurements for the stress-free grown plant leaves of different size, shape, and venation type show that the own growth rates $e^{g} \sim 0.1$, depending on the growth stage and availability of water and nutrients $\left[{ }^{11}\right]$. Image analysis of daily-taken digital pictures of separate leaves have revealed some regularities between the diameters and branching angles of the conducting elements (veins) in the junctions, diameters, and lengths of the separate veins and their influence domains (the areas of the leaf blade supplied by water and nutrients by the corresponding vein) $\left[{ }^{11}\right]$ that correspond to the model of the optimal transportation network of the rigid tubes with permeable walls $\left[{ }^{12}\right]$. Since the veins reinforce the leaf blade, whose mechanical strength and stability are determined by orientation, thickness, and branching angles of the main veins, the problem of optimal reinforcement of the biological tissues can be solved and the Nature-inspired composite materials may be constructed on the basis of our measurement data $\left[{ }^{13}\right]$. In this paper, the important problem for the growing fibrereinforced composite, connected with load transfer from the elongating fibre into the growing surrounding tissues, is considered.

\section{MATERIAL AND METHODS}

Plants of Abutilon hybridum, Plectrantus L., and Cissus rhombifolia were cultured in a phytotron. Daily-taken digital pictures were analysed using the computer software described in $\left[{ }^{11}\right]$. A set of Lagrange coordinates $\left(\xi_{j}^{1}, \xi_{j}^{2}\right)$ of fixed marks (vein junctions) on a growing leaf blade $(j=1 \ldots N, N=200-300$ junctions depending on the leaf size) were chosen and their coordinates measured on the consecutive pictures using the image analysis software. The Euler coordinate system $\left(x^{1}, x^{2}\right)$ was connected with the direction of the main vein and the point of attachment of the leaf to the petiole (see Fig. 1). The corresponding transition 


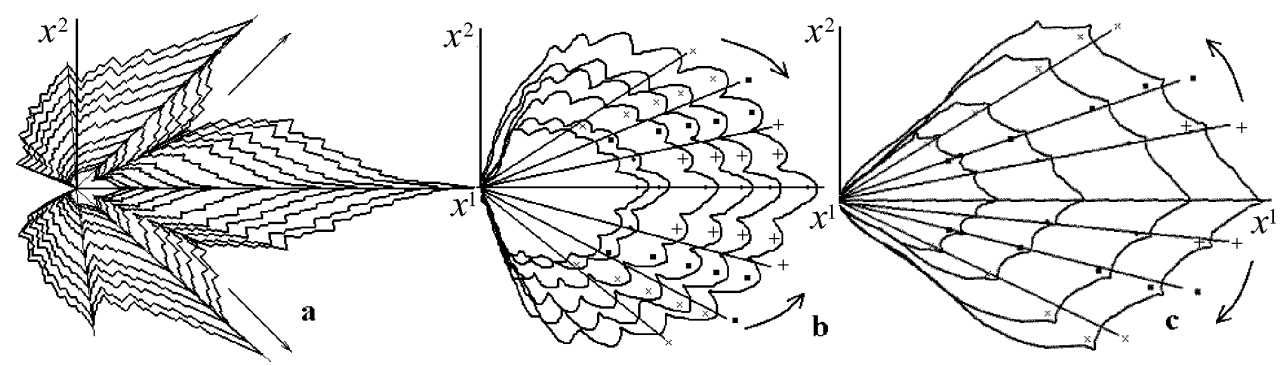

Fig. 1. Experimentally observed shapes of the isotropic growth of the Abutilon leaf (a), and anisotropic growth of the Plectrantus (b) and Cissus (c) leaves.

law $x^{1,2}=X^{1,2}\left(t, \xi^{1}, \xi^{2}\right)$ was determined in a usual way. The time series of the Euler coordinates $x_{j}^{1}, x_{j}^{2}$ of the marks $j=1 \ldots N$ was used for numerical calculations of the growth velocity field $\vec{v}$ and components of the strain rate tensor $\mathbf{e}_{\mathbf{i k}}=\left(\nabla_{\mathbf{i}} \mathbf{v}_{\mathbf{k}}+\nabla_{\mathbf{k}} \mathbf{v}_{\mathbf{i}}\right) / \mathbf{2}$.

It was established that for the Abutilon hybridum leaf the azimuthal component of the growth rate was practically zero $v_{\theta} \sim 0$ and the radial component $v_{r}=a(t) r$, where the function $a(t)$ depends on the growth regime (light, nutrition, and water availability) only (Fig. 1a). Hence growth deformations of the leaf plate are the similarity transformations. In that case the anisotropic plate exhibits isotropic growth. Anisotropy of the leaf is defined by the orientation of the main, secondary, and minor veins whose growth is anisotropic and connected with the extension of the veins in the longitudinal direction without any additional cell divisions and appearance of new cell walls. Some typical examples of anisotropy in fibre orientation and distribution are presented in $\left[^{1,11}\right]$. Growth of the main leaf tissue (mesophile) is determined by cell divisions in different directions and production of the isomorphic cells, which may be slightly elongated and oriented along the corresponding conducting element when they are near the vein. It means that the cell orientation and stimulation of the cell divisions in the main tissue can be determined by the load transfer from the growing vein into the mesophile. Generalization of Melan's problem of load transfer from the growing stringer into viscoelastic media with different growth rheology can be obtained in $\left[{ }^{14}\right]$.

Another growth kinematics was observed for Plectrantus and Cissus leaves, where $v_{r}=a_{r}(t) r, v_{\theta}=a_{\theta}(t) r \theta$, and $a_{r}>a_{\theta}$ for Plectrantus leaves (growth elongation of a leaf blade, see Fig. 1b) and $a_{r}<a_{\theta}$ for Cissus leaves (growth expansion that is especially noticeable for the leaf base, see Fig. 1c). The straight lines in Fig. 1b,c correspond to the similarity transformations of the leaf blade, while the marks "plus", "rectangle", and "multiplication sign" indicate the positions of the corresponding Lagrange points on the real growing leaf surface. In that case anisotropic growth (elongation) of the veins is combined with angledependent growth of the mesophile. 
Theoretical aspects of anisotropic volumetric growth are discussed in $\left[{ }^{15,16}\right]$. As far as orientation of the growing veins in the leaf cannot be only determined by genetic factors at variable natural conditions (wind and rain load, gravity) and fixed in space, variation of the angles between the main veins may be determined by the dependence of the growth of the main tissues on plant sap delivery through the corresponding vessel, while the flow rate of the sap is defined by the diameter of the vein $\left[{ }^{12,13}\right]$ and load transfer between the tissues or layers with different own growth rates $\left[{ }^{10,14}\right]$. In this paper the problem of the coordinated growth of the fibre and the main tissue (mesophile) by means of the stress field is investigated.

\section{PROBLEM FORMULATION AND SOLUTION}

We consider a $2 \mathrm{D}$ problem for the growing leaf with pinnate venation as a rectangular plate composed of the main vein $S_{1} \in\{x \in[0, L], y \in[-a, a]\}$ and the main tissue $S_{2} \in\{x \in[0, L], y \in[-h-a,-a] \cup[a, a+h]\}$ with different rheological properties. Due to symmetry, the upper part of the leaf is only considered (Fig. 2a). The strain tensor $\hat{\varepsilon}$ is supposed to be a sum of the elastic $\hat{\varepsilon}^{\mathrm{e}}$ and growth strain tensors $\hat{\varepsilon}^{\mathrm{g}}$. The tensor $\hat{\varepsilon}^{\mathrm{e}}$ obeys Hook's law $\hat{\sigma}=\hat{\mathbf{E}} \hat{\varepsilon}^{\mathrm{e}}$, where $\hat{\mathbf{E}}$ is the tensor of elastic moduli and $\hat{\sigma}$ is the stress tensor. In agreement with experimental data $D / D t\left(\hat{\varepsilon}^{\mathrm{g}}\right)=\hat{\mathbf{A}}+\hat{\mathbf{B}} \hat{\sigma}$, where $D / D t$ is time derivative, $\hat{\mathbf{A}}$ is the tensor of own growth rates (at zero stress growth), and $\hat{\mathbf{B}}$ is the tensor of the growth viscosities $\left[{ }^{1}\right]$. Finally we obtain the Maxwell model of the viscoelastic body with an additional source term. The momentum equation is considered in the static form due to large characteristic growth times $T^{*}=1-2$ days. Hence the problem formulation is presented by the momentum equations and constitutive equations for the two media $m=1,2$ with different rheological parameters:

$$
\hat{\mathbf{e}}^{\mathbf{m}}=\hat{\mathbf{A}}^{\mathbf{m}}+\hat{\mathbf{B}}^{\mathbf{m}} \hat{\sigma}^{\mathbf{m}}+\frac{\mathbf{D}}{\mathbf{D t}}\left(\left(\hat{\mathbf{E}}^{\mathbf{m}}\right)^{-\mathbf{1}} \hat{\sigma}^{\mathbf{m}}\right), \quad \operatorname{div}\left(\hat{\sigma}^{\mathbf{m}}\right)=\mathbf{0} .
$$

The boundary conditions are symmetry conditions at $y=0$; zero normal stress at the perimeter; growth rate and stress continuity conditions at the interfaces $y= \pm a$ and the attachment condition to the leaf petiole at $x=0$, namely:

$$
\begin{aligned}
& x=0: v_{x}^{1,2}=0 ; \quad y=0: v_{y}^{1}=0, \sigma_{y}^{1}=0, \sigma_{x y}^{1}=0 ; \\
& x=L: \sigma_{y}^{2}=0 ; \quad y=a: v_{x, y}^{1}=v_{x, y}^{2}, \sigma_{x, y}^{1}=\sigma_{x, y}^{2}, \sigma_{x y}^{1}=\sigma_{x y}^{2} .
\end{aligned}
$$

Solution of the problem (1)-(2) will be found as Fourier expansion on the basis of the results for the laminated growing composites $\left[{ }^{10}\right]$. Let us introduce the Airy functions $\Phi^{m}(x, y)=\sum_{n=0}^{\inf } \theta_{n}^{m}(y) \cos \left(\gamma_{n} x\right)$. Then the boundary conditions at $x=L$ are satisfied and the components of the stress tensors are

$$
\begin{aligned}
\sigma_{x}^{m} & =\sum_{n=0}^{\inf }\left(\theta_{n}^{m}(y)\right)^{/ /} \cos \left(\gamma_{n} x\right), \sigma_{y}^{m}=-\sum_{n=0}^{\inf } \theta_{n}^{m}(y) \cos \left(\gamma_{n} x\right), \\
\sigma_{x y}^{m} & =\sum_{n=0}^{\inf }\left(\theta_{n}^{m}(y)\right)^{/} \gamma_{n} \sin \left(\gamma_{n} x\right) .
\end{aligned}
$$


(a)

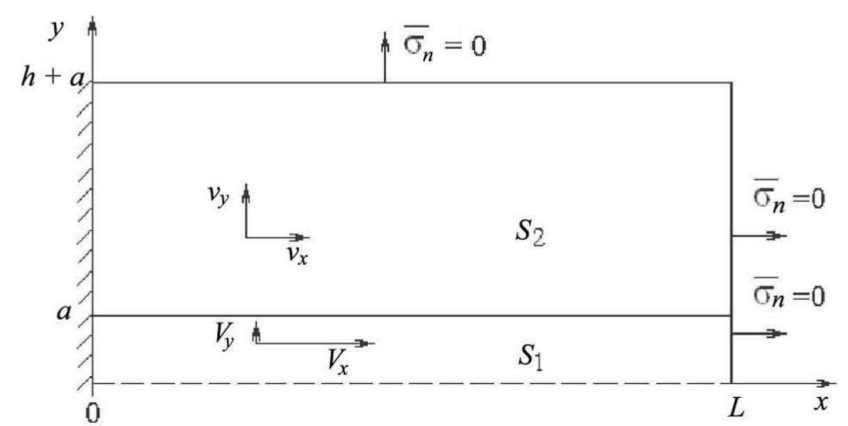

(b)

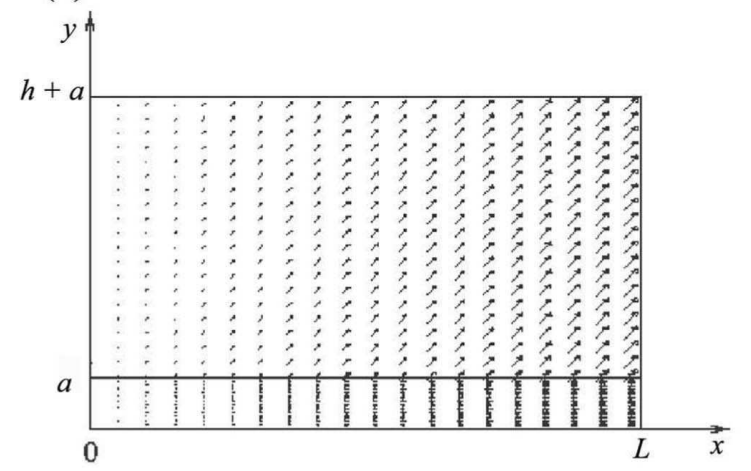

Fig. 2. Geometry of the system under consideration (a) and the growth rate field for the isotropic growth in two regions (b).

Substitution of (3) into (1) gives the fourth-order differential equations for determination of the functions $\theta_{n}^{m}(y)$. Solution of the problem can be easily obtained in the following form:

$$
\theta_{n}^{m}(y)=C_{1 n}^{m} e^{\lambda_{n}^{m} y}+C_{2 n}^{m} e^{-\lambda_{n}^{m} y}+C_{3 n}^{m} \cos \left(\mu_{n}^{m} y\right)+C_{4 n}^{m} \sin \left(\mu_{n}^{m} y\right),
$$

where

$$
\begin{gathered}
\lambda_{n}^{m}= \pm\left(\left(\zeta^{m} \pm\left(\Upsilon^{m}\right)^{0.5}\right) / 2\right)^{0.5}, \quad \zeta^{m}=\left(B_{12}^{m}+B_{21}^{m}+2 B_{3}^{m}\right) / B_{11}^{m} \\
\mu=\left(\left(\left(\Upsilon^{m}\right)^{0.5}-\zeta^{m}\right) / 2\right)^{0.5}, \quad \kappa^{m}=B_{22}^{m} / B_{11}^{m}, \quad \Upsilon^{m}=\left(\zeta^{m}\right)^{2}+4 \kappa^{m} .
\end{gathered}
$$

Substitution of (3) into (2) gives a set of algebraic equations for determination of the eight unknown coefficients $C_{1-4, n}^{m}, m=1-2$, which is not presented here for brevity. Solution of the obtained system was computed for the following ranges of the material and geometrical parameters that correspond to measurement data for different plant leaves: $L=1-30 \mathrm{~cm}, a=1-2 \mathrm{~mm}, H=0.2-5 \mathrm{~cm}, A_{11} \sim$ $A_{22}=0.05-0.2, A_{12}=A_{21}=0, B_{11} \sim B_{22}=2.5 \times 10^{-6}, B_{12} \sim B_{21}=$ $-(0.1-0.5) B_{11}, E_{i k} \sim 10^{6}-10^{8} \mathrm{~Pa}$. 


\section{RESULTS AND DISCUSSIONS}

When $A_{i k}=a_{i k}$, the problem (1)-(2) has a trivial solution $\sigma_{i k}^{1}=\sigma_{i k}^{2}=0$. A typical growth rate field is presented in Fig. 2b. In this case the size of the plate depends on the relation between $a_{11}$ and $a_{22}$ only. For instance, the kinematically different growth types obtained for the growing leaves and presented in Fig. 1a-c can be achieved here at $a_{11}=a_{22}, a_{11}>a_{22}$, and $a_{11}<a_{22}$, respectively. The relations may be connected rather with features of the growth at a cellular level (fibre orientation and distribution in the cellular wall and concentration of the phytohormones) than with the mechanical factors $\left[{ }^{3}\right]$. When the fibre exhibits the anisotropic growth and $A_{22}=0$ while $a_{11}=a_{22}<A_{11}$, the stress concentration is observed at the interface $y=a$ only. For clarity the distribution of the stress intensity $\sigma^{\circ}$ is given in Fig. 3a at $a_{11}=a_{22}=0.1, A_{11}=0.2$. Computer simulations for the mentioned ranges of the material parameters revealed that the region with $\sigma^{\circ} \neq 0$ is placed along the interface and is quite narrow $(d \leq a)$. As an illustration the growth rate field for the regions with different rheological parameters $A_{i k}$ and $B_{i k}$ is plotted in Fig. 3b. Far from the interface the growth is not affected by the stress field and is governed by the own growth rate $a_{i k}$

(a)

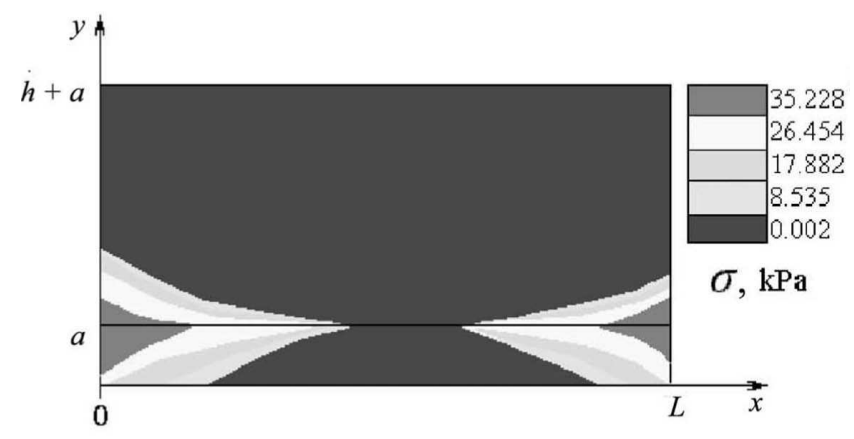

(b)

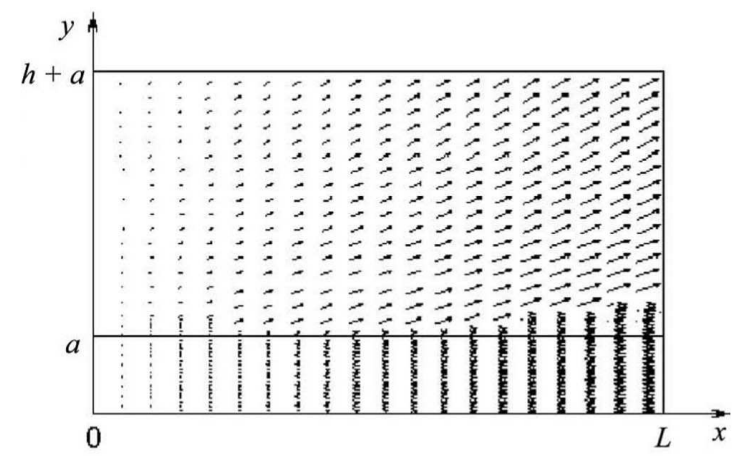

Fig. 3. Stress intensity distribution (a) and the growth rate field (b) for nonuniform growth. 
only. The same result has been obtained by FEM calculations for the plates with $a_{11}=a_{22}>>A_{11}$ (growth restriction along the fibre). In that way the stress field provides a local growth coordination within several cellular layers. When the parameters $A_{i k}$ and $a_{i k}$ differ significantly, the rectangular shape of the form is not maintained and the problem can be solved by the FEM. As far as in plant leaves the initial shape (for instance, the considered initial rectangular shape) is kept during the growth, it means that there are no significant differences in $A_{i k}$ and $a_{i k}$, though growth mechanisms may be different in veins (elongation) and in the attached mesophile (cell divisions). When $a \sim h$, the differences in $A_{11}$ and $a_{11}$ may lead to growth instabilities and shape variations far from the allometric law as discussed in $\left[{ }^{6,7}\right]$. This will make the subject of further investigation.

\section{ACKNOWLEDGEMENTS}

I thank the organizers of the Euromech Colloquium 478, Prof. Jüri Engelbrecht and Prof. Arkadi Berezovski, the participants in the Colloquium, and especially Prof. Gerard Maugin for stimulating discussions on the subject and a promising new insight into the problem consideration and data analysis.

\section{REFERENCES}

1. Belousov, L. V. and Stein, A. A. (eds). Mechanics of Growth and Morphogenesis. Modern Problems of Biomechanics, Vol. 10. Moscow University Press, Moscow, 2002.

2. Cowin, S. C. Strain or deformation rate dependent finite growth in soft tissues. J. Biomech., 1996, 29, 647-649.

3. Schopfer, P. Biomechanics of plant growth. Amer. J. Botany, 2006, 93, 1415-1425.

4. Cosgrove, D. J. Wall relaxation and the driving forces for cell expansive growth. Plant Physiol., 1987, 84, 561-564.

5. Entov, V. M. Mechanical model of scoliosis. J. Mech. Solids, 1983, 18, 199-206.

6. Stein, A. A. Deformation of the rod from the growing biological material at longitudinal compression. Appl. Math. Mech., 1998, 59, 149-157.

7. Kantor, B. Ya. and Kizilova, N. N. Mechanics of growing biological continuum. Proc. Nat. Acad. Sci. Ukraine, 2003, 2, 56-60.

8. Kantor, B. Ya. and Kizilova, N. N. Stress-strain state investigation in bidimensional growing biological material at growth restrictions. Kharkov Nat. Univ. Vestnik, 2003, 582, $107-120$.

9. Stein, A. A. and Logvenkov, S. A. Space self-organization of a thin layer of the biological material growing on the substrate. Rep. Russian Acad. Sci., 1993, 328, 443-446.

10. Kizilova, N. N. and Egorova, E. S. Modelling of laminated growing biological materials. J. Mech. Eng., 2005, 56, 330-342.

11. Kizilova, N. N. Computational approach to optimal transport network construction in biomechanics. Lect. Notes in Computer Sci., 2004, 3044, 476-485.

12. Kizilova, N. N. Hydraulic properties of branching pipelines with permeable walls. Int. J. Fluid Mech. Res., 2005, 32, 98-109.

13. Kizilova, N. N. Construction principles and control over transport systems organization in biological tissues. In Physics and Control International Conference Proceedings. IEEE Computer Society, Washington, 2003, 1, 303-308. 
14. Kizilova, N. N. and Kravchenko, H. P. Investigation of stress-strain state of the 2D growing media. Mech. Solid Body, 2003, 33, 158-168.

15. Maugin, G. A. and Imatani, S. Anisotropic growth of materials. J. Physique IV (Proceedings), 2003, 105, 365-372.

16. Menzel, A. Modelling of anisotropic growth in biological tissues. Biomechan. Model. Mechanobiol., 2005, 3, 147-171.

\title{
Koormuse ülekanne kasvavalt kiult kasvavale keskkonnale: rakendus taime lehe kasvu kirjeldamiseks
}

\author{
Natalya Kizilova
}

Bioloogilised materjalid muudavad kasvuprotsessis oma massi, kuju ning poorsust, moodustades tugevaid ja vastupidavaid ning seejuures kergeid struktuure. Artiklis on vaadeldud bioloogilisi kudesid mittehomogeensete anisotroopsete mitmefaasiliste komposiitidena, mida tugevdavad kiud. On vaadeldud kahemõõtmelist koormuse ülekannet kasvavalt kiult kasvavale plaadile, kui kasvukiirused ja viskoossused kius ning plaadis on erinevad. Kasvavate bioloogiliste kudede reoloogiat on kirjeldatud Maxwelli viskoelastse keskkonna mudeli abil. Numbriliselt on leitud kasvu kiiruste ja pingevälja väärtused. On uuritud kahe keskkonna reoloogiliste parameetrite mõju pingeolukorrale. On näidatud, et pingeväli võib kiu ja plaadi materjalide erinevate reoloogiliste parameetrite korral tekitada omavahel seostatud kiu ja plaadi kohalikku anisotroopset kasvu. 